Global Conferences Series:

Social Sciences, Education and Humanities (GCSSSEH), Volume 3, 2019

The $1^{\text {st }}$ International Conference on Education, Social Sciences and Humanities

DOI: https://doi.org/10.326/hum0209

\title{
Teaching Vocabulary by Using Visual Auditory Kinesthetic Tactile (Vakt) for Autism Students
}

\author{
Kasiyati ${ }^{1}$, Zulmiyetri ${ }^{2}$, Nurhastuti ${ }^{3}$, Mega Iswari ${ }^{4}$ \\ ${ }^{1234}$ Universitas Negeri Padang, Padang, Indonesia, \\ $\left.{ }^{*}\right) \bowtie \underline{\text { kasiyati@fip.unp.ac.id }}$
}

\begin{abstract}
Abstrak
This research aims to determine the influence of visual auditory kinesthetic tactile (VAKT) to improve vocabulary of students with autism. The approach of this research is using quantitative research with experimental research type. Experimental approach used in this research is Single Subject Research (SSR) approach. The design in this study used A1-B design. The research subject is students with autism in SLB Khansa Padang. Data collected through descriptive statistics and displayed in graphical form. The components were analyzed by an analysis of the condition. Result of this research showed that visual auditory kinesthetic tactile (VAKT) indicate a significant influence in improving the target behavior
\end{abstract}

Key words : visual auditory kinesthetic tactile, vocabulary, autisms

\section{Introduction}

Understanding vocabulary is the first step in language development. An adequate vocabulary will facilitate the students in understanding language which is the basis of knowledge. Because vocabulary is the smallest element of language that has meaning. According to Danuatmaja (2004:141), students who mastering the language will also understanding the knowledge because students can understand the lesson that presented by other people (parents and teachers) as well as contained in the textbooks which can eventually facilitate in communicating.

According to Sutadi (2003:70) language skills will help students to understand that presented by teachers and eventually pupils will be able to communication. Therefore,vocabulary in speaking is one of ability that must be learned in any educational materials, including education for students with autism. Students with autism need to master the vocabulary. Because, by understanding the vocabulary the students can understand the material that presented by other people and learn everything that related with the environment. Finally, they can be able to operationalize in daily life while communicating and interacting with people. In line with Keraf (2006: 65), in order to have easy communicating, every people need to expand vocabulary and need to know as much as vocabulary in the language".

Students with autism tend to show the behavior such as difficulties in language, both expressive and receptive, attention, sorting, planning and organizing information on the results of learning. Students with autism as if living in their own world. Its symptoms can be detected when children aged 18-3 of the month sudden refuse the presence of people, act strangely and decreasing in communication as well as socialization skills. The symptoms that arise in children with autism such 
as social interaction, communication and language disorders as well as behavior and interests disorders.

Communication disorders of students with autism in daily living is characterized by difficulty understanding words spoken by others, for example when students with autism was given instruction to take the ball (grab the ball) they just stay quiet don't respond or parroting the instructions. This is happen because they are still struggling to understand the intent of the word "take" and "ball"(Yuwono, 2009:64). The child also use words without understanding the meaning, communicate with body language and communicate in a short time, imitating the words, sentences or songs without understanding the meaning,talk without expression and flat expression, even showing the words that can not understood by other people as well as not using the words in appropriate context, and echolalia (parroting).

The results of the observation in the SLB Khansa Padang indicate the presence of students with autism conditions, especially in understanding vocabulary. They do not understand the meaning of word that presented by teacher or therapist. Understanding is only limited to a word that is heard such as grab, grasp, point. Students are still confusing identify, pointing or doing something against the objects such as take the ball, the child actually pick up another objects and looks of confusion. In addition, when shown the objects the students is still difficult to mention the name of the object, similarly, when the students wants something, for example "ball" or "milk" the students do not expresses their desire, but only grab the hand of the teacher or therapist. Students also tend to be parroted, they are only capable of imitating and following recite the words or song that they heard without understanding the meaning or its meaning.

Students with autism are easier to understand concrete things with all the senses through tactile, vision, kinestetis, smell and hearing process. Therefore in learning process, students with autism need a method that can provide a stimulus that integrated all of sensory. Similarly, in learning process, as an effort to control vocabulary, needs methods that using observation priciple through integrated senses i.e., sight (visual), hearing (audio), movement (kinesthetic) and palpation (tactile) to the learning process.

Every student in every school has rights to get educational service based on their ability (Yusuf \& Kusumastuti, 2016). The characteristics of learning satyles that needed by students with autism according to Sadjaah (2005:47), which suggests that the more students are seen, heard, touched, or felt and kissed the object, students will be more developed in perception. The more feedback obtained, the more developed in language including vocabulary. As well as that presented by Rose, Colin and Malcolm J. Nicholl (2002:192), see, hear, say, and do something more, the easier to learn.

Visual auditory kinesthetic and tactile methods is known as multisensori that used for teaching speech in deaf children and start reading to the students dyslexia as well as the students in early childhood level. This method can be used in the effort of vocabulary acquisition in students with autism because in reading and speaking process are equally demanding aspects of vocabulary acquisition which includes the understanding and meaning of the word. Danuatmaja (2004:66)states that language learning is a tool of communication so that in teaching a language not only taeching words but also should be able to teach how students communicate, whereas in communication required an understanding the vocabulary. Prasetyo (2008:207) stated that language learning in students with autism aims to improve the ability to communicate verbally

Based on these problems, needs to solve the problem that can help students' problem. Learning method can be used in according to solve the problem. Learning method can be adjusted with its characteristics, including methods that involve a variety of sensory to fix the barriers of language and vocabulary skills of students with autism. By using more senses, it will help the students to understand the lesson and stimulate the students to communicate. Based on this background, this 
research aims to determine the influence of VAKT method to improve understanding vocabulary in students with autism in special school Khansa Padang.

\section{Method}

This research was conducted in SLB Khansa Padang. Students with autism were given the intervention through VAKT (visual auditory kinesthetic tactile) to improve the understanding of vocabulary. The research method used in this research is a quantitative type of research. This research used experimental design with single subject research (SSR). Design that used in this research is reserval with the pattern A-B. Data analysis techniques in this study is the use of visual analysis between conditions, which was presented through graphs and tables.

\section{Result and Discussion}

Data presented is data result from research implementation for twenty days that divided in eight days of baseline phase (one day and one session for 25 minutes). Then continued with twelve days included intervention phase (one session for 25 minutes).Data collected on baselilne phase (A) and interventions phase (B) describe in following graphic.

Figur 1 shows the traces data of each session both the phase of baseline and intervention. Figure 1 shows students' ability to follow the instructions that given by teacher. Figure 1 also showing response made by students towards the instructions that given by teacher. Based on Figure 1, it clearly difference in the comparison of students' understanding of instructions that given by the teachers. Students' understanding of vocabulary has increased from the baseline phase to intervention phases. After data was collected, then data were analyzed by in conditions data analysis.

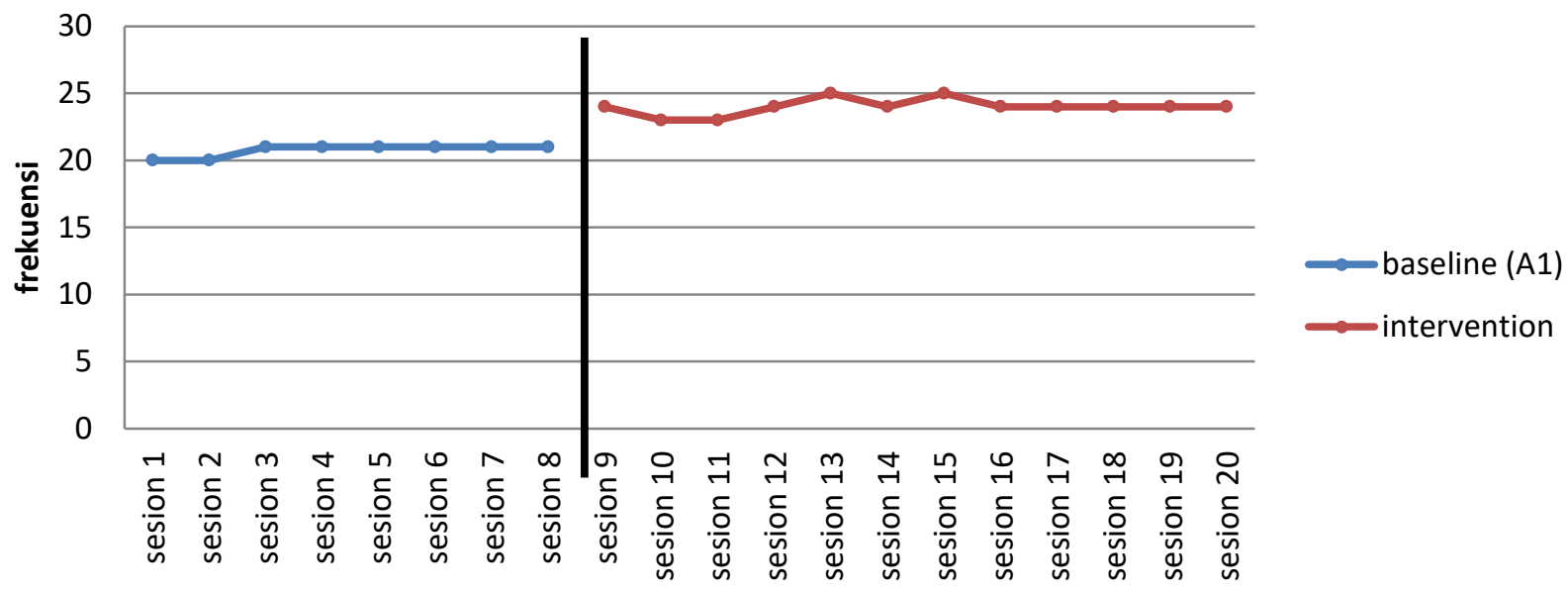

Figure 1Baseline (A) and Intervention (B) phase

Tabel 1. Analisis dalam kondisi

\begin{tabular}{|c|c|c|}
\hline Condition & $\mathbf{A} / \mathbf{1}$ & $\mathrm{B} / 2$ \\
\hline Condition length & 8 & 12 \\
\hline \multicolumn{3}{|l|}{ Estimation } \\
\hline & $(+)$ & $(+)$ \\
\hline Stability & Stabil & Stabil \\
\hline \multicolumn{3}{|l|}{ Trend } \\
\hline & $(+)$ & $(+)$ \\
\hline
\end{tabular}




\begin{tabular}{ccc}
\hline Stability level and range & Variabel & Variabel \\
& $(20-21)$ & $(23-25)$ \\
\hline Changing level & $21-20$ & $25-23$ \\
& $(+1)$ & $(+2)$ \\
\hline
\end{tabular}

Based on analysis that has been presented in the Table 1 shows the change of the range of values in the understanding vocabulary. This is evidenced by the different results when baseline phase(A) and intervention phase. The ability of the subject to follow instructions that given by teachers has increased. On baseline phase a subject shows difficulty in following instructions which given by the teachers correctly. The subject has a lot of mistakes in following the instructions and does not respond, just quietly looking at the teacher. While the intervention phase, the ability to follow the instructions that given by the teachers has increased. The range of data points of the baseline between 20 to 21 , while the intervention phase between 23 to 25 . Trend direction on baseline and intervention phase indicate the direction which means that there is positive increasing in the ability to follow instruction.

The description of the results, in line with Sadjaah (2005:47) who argued that the more objects are seen, heard, touched, or felt, then it will be more rapidly progress the development of perception and the more feedback obtained, the more rapidly the development of language including vocabulary. As well as that submitted by Collin, et al (2002:192), more to see, hear, say and do something, it is easier to learn.

Visual auditory kinesthetic tactile (VAKT) methods is a method that optimizes all the senses potential that facilitated the children in learning process. In this study the method of visual auditory kinesthetic tactile (VAKT) is used for mastery of the vocabulary of students with autism. If viewed from the characteristics of children with autism, children with autism will learn more effetive if they learn by given concrete concept. Something concrete that can be absorbed through their senses such as vision, hearing, and motion and palpation in order to easily understand what they are learning. In the learning process of autistic children required objects or media that can represent the use of his senses, so that in the learning process the students shown the image or object directly by mention the name of the objects as well as commenting on the objects which attract his interest to master the concept of noun, adjective, or verb as described by Maulana (2011:79) that way of teaching vocabulary for students with autism is through giving real object or picture and gesture following with spelling the name repeatly.

\section{Conclusion}

Based on the results, it can be concluded as follows: (1) the visual auditory kinesthetic tactile (VAKT)method, as the intervention, indicate a significant influence in improving the target behavior, (2) On baseline phase, subject shows difficulty in following instructions that given by the teachers. The subject is still difficult in following instructions that given by the teachers. Even, students did not respond or just silent and staring at the teacher, (3) on the intervention phase, the capability of the subject in following the instructions that given by the teachers was increasing. Trend direction shows the direction of the trend is ascending, which means there is a change good or positive.

\section{References}

Abdurachman, Dudung. (2000). Pedoman Guur Pengajaran Wicara untuk Anak Tunarungu.Jakarta: Departemen Pendidikan dan Kebudayaan.

Azwandi, Yosfan. (2005). Mengenal dan Membantu Penyandang Autisme.Jakarta : Depdiknas

Danuatmaja, Bonny. (2004). Terapi Anak Autis di rumah.Jakarta: Puspa Swara

Gunadi. (2005). Terapi Integrasi. Jakarta: dalam Pelatihan Dasar Sensory Integrasion Therapy

Handojo. (2006). Autisme. Jakarta: PT Buana Ilmu Populer 
Keraf, Gorys. (2000) Diksi Gaya Bahasa. Jakarta: Gramedia

Mirza, Maulana. (2011). Anak Autis. Jogjakarta: Kata Hati

Prasetyono, D.S. (2008). Serba-Serbi Anak Autis. Jogjakarta: Diva Press

Rose, Collin dan Malcolm J, N. (2002). Accelerated Learning. Bandung: Nuansa

Sadjaah, Edja. (2005).Pendidikan Bahasa bagi Naka Gangguan Pendengaran dalam Keluarga. Jakarta: Depdikbud

Safaria, Triantoro. (2005). Autisme. Yogyakarta: Graha Ilmu

Sutadi, Rudi. (2002). Autisme dan Applied Behavior Analysis (ABA). Jakarta: Klinik Intervensi Dini Autism.

Yusuf, M., \& Kusumastuti, G. (2016). A Study of Gifted Students' Academic Preference and The Implications of Development Process. In Proceeding2nd International Conference on Education and Training (pp. 608-612). 